\title{
Applying Possessive Pronoun in Writing Sentences: Exploring Students' Ability and Problems in a Mixed Method Study
}

\author{
Syahdan Syahdan ${ }^{1}$ and Eka Utami Putri ${ }^{2}$ \\ ${ }_{1,2}$ Universitas Lancang Kuning, Pekanbaru, Indonesia \\ amyeka.black87@gmail.com
}

\author{
Received : 2019-12-21 \\ Revised : 2019-12-21 \\ Accepted : 2019-12-29
}

ARTICLE HISTORY

\section{KEYWORDS}

Possessive pronoun

Writing

Mixed method

Ability

Problems

\begin{abstract}
The purpose of this research was to find out the students' ability in applying Possessive pronoun in writing sentences and the problems encounter it. This mixed method study employs an explanatory design to reveals it. 53 students out of 105 students from the first semester EFL students from one reputable University in Pekanbaru, Indonesia, were invited to this study. These 53 students were selected using simple random sampling and enrolled for an essay test and interview to see the students' ability and explaining the problems. The data analysis using SPSS showed that the average score of students was 52.98. Meanwhile for the median is 48 , the mode is 20. The score of Standard Deviation is 27.93 , Variance is 780.25 , and Range is 84 . Z-Score was found $41.5 \%$, which is means higher than average and $58.5 \%$ while, students' ability was indicated below the average. It showed that the students were low ability in applying possessive pronoun in writing sentences. The study also found the common problems, i.e., (1) students still mixed up between possessive pronoun and possessive adjectives. (2) students used the wrong pattern in using a possessive pronoun. (3) students did not understand clearly about a possessive pronoun, (4) experiencing difficulties in learning possessive pronoun.
\end{abstract}

\section{Introduction}

Grammar is an important aspect of English. Even though grammar is not one of the skills in English but grammar determines the quality of skills produced. Grammar is useful in writing aspect because grammar helps in constructing a good sentence. Another reason is grammar makes the writing easily understood by the audience, in this case, the reader. Therefore, the knowledge regarding how to construct sentences include grammar itself. Furthermore, grammar has also some function in writing. The function of grammar is to organize the sentence pattern so the writer can get the emotions expected to express. Grammar itself is a study on how to organize words becoming a sentence with meanings. One of the materials in grammar is Personal pronoun. A personal pronoun is to substitute for a noun. The personal pronoun can be classified into Subject pronoun, Object pronoun, Possessive adjectives, and Possessive pronouns.

There are some functions in using Possessive pronoun. As explained before, Possessive pronoun is a substitution for a noun in subject or object. One of the functions of using Possessive pronoun is efficiency. The efficiency of Possessive pronoun in a sentence is to avoid repetition. There is an indication in writing Possessive pronouns that students are mixed up between Possessive Adjectives and Possessive pronouns. Another thing is in choosing whether it uses Possessive Adjective or Possessive pronouns. Dealing with this research, the researcher used a mixed method. A mixed method is a combination of two designs; quantitative and qualitative. The reason for choosing mixed method because the researcher interested to identify the ability and the students' common problem in applying possessive pronoun.

\subsection{Sentences}

Based on Baskaran (2005:83) sentences can be categorized according to their communicative function or according to their structural components. It is mean each kind of sentence will have a communicative purpose. Each sentence has a different function depending on the meaning behind it. Sentences have a different meaning in each part of it. The meaning of the sentences is various in every single part. The sentences always have different purpose for each topic. So, sentences are a tool for communication that brings different meaning in every part.

\subsection{Grammar}

According to Thornburry (2000:1), grammar is partly the study of what forms (or structures) are possible in a language. This can be interpreting that grammar is a study that learns how to construct a form in a possible language.

This also means that grammar is important to make the sentence have meaning and understandable. The construction or forms is helping to make a 
meaningful sentence. Furthermore, Baskaran (2005:58) said that the word "grammar" in linguistic can be taken to mean the entire system of describing the structure of a language from its sounds system to its meaning system or just the organization (form) of words (morphology) and arrangement of these words into sentences (syntax). It can be concluded that grammar is an organized pattern from words and arrange it into sentences that have meaning. Baskaran (2005:58) stated there are four identifiable kinds of grammar, theoretical grammar, descriptive grammar, pedagogic grammar, prescriptive grammar.

Moreover, grammar itself is an important pattern in English. The language structure in English is coming from grammar. Grammar is arranging the pattern from words until becoming a sentence. Grammar plays an important role to make sentence understandable. Grammar constructions make the structure become meaningful. So, grammar is a part of English that study the pattern and structure of a sentence.

\subsection{Pronoun}

Pronoun is a word that used to refer to someone or something. The most common pronouns are the personal pronouns, which refer to the person or people speaking or writing (first person), the person or people being spoken to (second person), or other people or things (third person). Frank (1972) "classifies pronouns into seven types. They are personal, interrogative, relative, demonstrative, reflexive, indefinite, and expletive.".

According to Payne (2011:122), pronouns are referring expressions that can be thought as abbreviated versions of a determined noun phrase. This means pronouns are part of a noun phrase. As explains above, pronouns also can be directed expression. Pronouns itself is an important material to determine part in a noun phrase. Based on Rozakis (2003:3), pronouns are a word used in place of a noun or another pronoun. It can be interpreted that pronouns can be a replacement. Pronouns itself is a changing word to a noun. Pronouns also can change or replacing another pronoun.

Leech and Svartvik (2003:253) also stated that pronouns are words which can function as a whole noun phrase (e.g. in being subject or object of a clause) or as the head of a noun phrase. Based on the expert above, pronouns can act as a phrase or main phrase. Pronouns also can be a subject of a phrase or sentence and also an object of a phrase or sentence. It is also can stand alone in one phrase or act as the main phrase. In addition, Quirk et al. (1985:335) state that pronouns are several characteristics, most of which are absent from a noun. Pronouns are used as a substitution for a noun. Pronouns itself is considering as an important part in writing a sentence. Further, pronouns are an expression that used for a noun.
Pronoun itself can be a substitute or replacement for a noun or another pronoun in the sentence. Pronouns also can be subject or object in a sentence. So, a pronoun is an expression to substitute the noun.

\subsubsection{Personal pronoun}

Based on Danesi (2006:77) Personal pronoun is classified according to the person(s); the person speaking (first person); the person spoken to (second person); anyone or anything else (third person). Personal pronoun is a part of pronoun that usually substitutes the subject or object in a sentence. Rozakis (2003:10) also stated that Personal pronoun refers to a specific person, place, object, or thing. It can be concluded that Personal pronoun can refer to anything. It should not be just a person; it can be a place, object, or things. That's the reason why Personal pronoun still has subcategory to explain the substitute for subject and objects. Personal pronoun is a part of pronoun. Personal pronoun is including many things to substitute a noun. Personal pronoun can substitute place, item, and person. Personal pronoun is also including possession of an item.

\subsubsection{Possessive pronoun}

Based on MacFayden, a possessive pronoun indicates that the pronoun is acting as a marker of possession and defines who owns a particular object or person. In other word, a possessive pronoun is substituting an object or subject of possession. Possessive pronoun is a pronoun that used for marks a possession. Possessive pronoun also explains the owner of the object or person. Possessive pronouns are in a different state with Possessive Adjectives. Possessive pronoun is not followed by a noun after the word. The possessive pronouns are "mine," "yours," "hers," "his," "its," "ours," and "theirs".

\section{Method}

The research was conducted with mixed methods research. Creswell (2005: 510) stated that mixed method research is a procedure for collecting analyzing, and "mixing" both quantitative and qualitative data in a single study to understand a research problem. The researcher took explanatory research for this mixed method research. According to Creswell (2005: 515), an explanatory design (also called a two-phase model) consists of first collecting quantitative data and then collecting qualitative data to help explain or elaborate on the quantitative results. It can be explained that the researcher collected the quantitative data first and follow up with qualitative data to build a stronger result.

The research was conducted at the Faculty of Education and Teachers Training Lancang Kuning University in Jl. Yos Sudarso Rumbai. The research conducted in January 2016. The population for this research was the 1st-semester FKIP UNILAK Pekanbaru. As for the sample of this research was 
simple random sampling. It means all of the students in the first semester had the same chances to be chosen as sampling. It was chosen by lottery. As for the number of samples, the researcher uses Saleh (2008) table like below:

Table 2.1 Sample Based on Saleh (2008)

\begin{tabular}{cc}
\hline POPULATION & SAMPLE \\
\hline$<100$ & $50 \%$ \\
$101-500$ & $30 \%-50 \%$ \\
$501-1000$ & $20 \%-30 \%$ \\
$<1000$ & $15 \%-20 \%$ \\
\hline
\end{tabular}

The population for this research is 105 students; the sample was $50 \%$ of the population. In other words there were 53 students for the sample. There were two instruments of this research. The first one was tested. The test has been used to collect quantitative data. The second one was an interview. The interview was used to collect qualitative data. The qualitative data was used to support the result of quantitative data. The quantitative data for this instrument was tested. The test was the first instrument that researcher does in this research. The test is one of the instruments in quantitative data to answer the first research question in this research. The purpose of this test is to analyze the statistic of student ability in applying Possessive pronoun.

The researcher provided the students with an essay question related to Possessive pronoun. The researcher asked the students to make a sentence that including Possessive pronoun in it. There were 25 sentences, and each Possessive pronoun has 4 items. Each of the questions scored 4 points to analyze the quantitative data, and this present study applied descriptive analysis as presented at the following diagram:

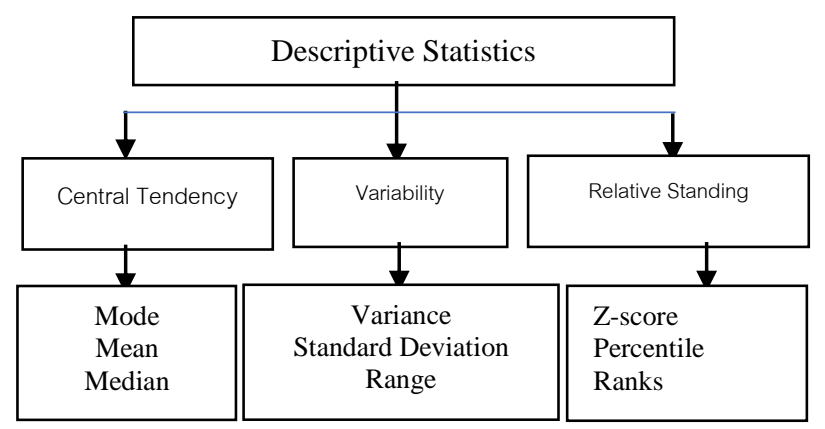

Figure 2.1 Descriptive Statistics

This instrument used to support the result of this research from the quantitative data. It was also to answer the second research question. An interview was an instrument that asks of some question to the students that has a function to collect the information from participants. Based on Creswell (205:214), a qualitative interview occurs when the researcher asks one or more participants general, open-ended questions and record their answer. The interview allows the participant to answer the question in his own words.

For this research, the researcher conducted a focus group interview. Focus group interview was used to collect the sharing data from some individual. According to Creswell (2005:215) focus group interview is the process of collecting data through interviews with a group of people, typically four to six. It means that a focus group interview was an interview with a group consisting of four to six people and only one person that represent the others. Furthermore, the next step was to display the data for explanatory data analysis. The data received from the test were analyzed by descriptive statistics. The descriptive analysis result has used to answer the first formulation of the research. For the second formulation of the research, the researcher conducted an interview to ask them about their common problem in applying Possessive pronoun. The data from the interview was used to support the result from the descriptive analysis result. The last, the researcher describe both the descriptive analysis result and also the student's common problem in applying Possessive pronoun.

\section{Findings}

The researcher did the test to all of the first semesters in Lancang Kuning University on January 7th 2016 to find out students ability in applying Possessive pronoun in writing sentences. The test was given to answer the first question in this research. The first question is "How is students' ability in applying Possessive pronoun in Writing Sentences at the 1st semester Lancang Kuning University?" in order to answer this question, the researcher gave an essay question to the sample of this research. The test consists of 25 numbers.

\subsection{The Ability in Applying Possessive Pronoun}

According to the descriptive statistics data from the research, the finding for the whole participants (53 students) concluded that the ability of the firstsemester student in applying Possessive pronoun is low. It was supported by the result of the test and in accordance with the interview. Based on the presentation of data analyzing above, the finding of this research led me to infer that the students' ability in applying Possessive pronoun was categorized into low. The data gained was analyzed by using descriptive statistics to find the sum, mode, median, mean, variance, standard deviation, range, Z-score, and percentile rank. The sum used to find the calculation of the student's raw score. The total scores of students' ability in applying Possessive pronoun are 2808. The mode is used to find out the score that occurs the most. The mode of the student's score is 20 . The median is the middle score among all of the score. 
Median scores were got when the score is rank from top to bottom and divide it into two. The median of the score is 48 .

The variance indicates the dispersion of scores around them. The variance of the student's score is 780,25 . This information is a useful number when calculating the statistics to make it more advances. The standard deviation is used to look on it as an indicator of dispersion or spread of the scores. The standard deviation is 27, 93. The lower standard deviation from the mean, the smaller variant of the score will be. It means that the students' ability is homogeneous. The range of the score is the difference between the lowest and highest scores.

Furthermore, the highest scores are 100, and the lowest score is 16 , a range of 84 points. A percentile rank of a particular score is the percentage of participants in the distribution with scores at or below the score. It was used to determine where in a distribution of scores an individual's scores lie in comparison with other scores.

To describing the percentile rank of this research, it can be seen that the highest percentile rank $100 \%$ occurs in the score 100 , the second percentile rank 84 , $8 \%$ occurs in the score 96 , and the third $86,9 \%$ occurs in the score 84 . The data also reveals Z-score is the score was zero. Zero categories as average. $41,5 \%$ of students were higher than average. $58,5 \%$ of students were lower than average. It can be described that most of the student's ability still below average for applying Possessive pronoun in writing sentences.

The mean used to describe the score from the entire sample. A mean is a total score divided by the number of samples. The mean gives us the average of the score. The mean is 52, 98. It can be concluded that the students' ability in applying Possessive pronoun is low.

\subsection{The Students' Common Problems}

Based on data from the test and supported by the interview, it can be categorized into two groups namely;

First, the students' common problem in applying Possessive pronoun from the test such as students still mixed up between Possessive pronoun and Possessive Adjectives, students use the wrong pattern in using Possessive pronoun, students still use Subject or Object pronoun.

Second, the students' common problem in applying Possessive pronoun from the interview such as students did not understand clearly about Possessive pronoun, students have difficulties in learning Possessive pronoun, students rarely review the lesson about Possessive pronoun at home, and students often use Possessive pronoun in daily activities.

\section{Conclusion}

Based on the presentation of data analyzing above, the finding of this research led me to infer that the students' ability in applying Possessive pronoun was categorized into low ability. While, the students' common problem in applying Possessive pronoun from the test such as students still mixed up between Possessive pronoun and Possessive Adjectives, students use the wrong pattern in using Possessive pronoun, students still use Subject or Object pronoun. Second, the students' common problem in applying Possessive pronoun from the interview such as students did not understand clearly about Possessive pronoun, students have difficulties in learning Possessive pronoun, students rarely review the lesson about Possessive pronoun at home, and students often use Possessive pronoun in daily activities.

\section{Acknowledgement}

This research was partially supported by Kumon Pekanbaru. We thank our colleagues from Applied Linguistic Center FKIP Unilak who provided insight and expertise that greatly assisted the research, although they may not agree with all of the interpretations of this paper.

\section{References}

Abbas, M. F. F., \& Herdi, H. (2018). Investigating EFL Learners' Ability in Generating, Organizing, and Elaborating Ideas in an Argumentative Essay. J-SHMIC: Journal of English for Academic, 5(2), 39-47.

Baskaran, L. M. (2005). A Malaysian English primer: aspects of Malaysian English features. University of Malaya Press.

Brown, H. D. (2007). Principles of language learning and teaching fifth edition. White Plains, NY: Pearson Education.

Clark, V. L. P., \& Creswell, J. W. (2005). Student study guide to accompany Creswell's educational research: planning, conducting, and evaluating quantitative and qualitative research. Merrill.

Danesi, M. (2006). Basic American grammar and usage: An ESL/EFL handbook. Barron's Educational Series.

Firdausi, D. H. (2014). An Analysis on Students' Errors in Using Personal Pronouns.

Handayani, R., Ihsan, D., \& Mirizon, S. (2019). Interlanguage analysis of syntactic and diction errors found in theses written by magister students. International Journal of Indonesian Education and Teaching (IJIET), 3(1), 102-116. 
Herlinawati, H. (2014). Feedback in English Writing for Indonesian EFL Students. ELT-Lectura, 1(1).

Hyland, K. (2018). Metadiscourse: Exploring interaction in writing. Bloomsbury Publishing.

Leech, G. N., Leech, G., \& Svartvik, J. (2002). A communicative grammar of English. Pearson Education.

MacFayden, Heather. The Parts of Speech. uOttawa. Retrieved on December 20 $0^{\text {th }}$ (2015) from http://arts.uottawa.ca/writingcentre/en/hypergr ammar/the-parts-of-speech

McArthur, T., Lam-McArthur, J., \& Fontaine, L. (Eds.). (2018). Oxford companion to the English language. Oxford University Press.

Nurhasadah. (2014). An Analysis on Students Error in Using Personal pronoun. UIN Syarif Hidayatullah. Jakarta

Payne, T. E., \& Payne, T. E. (2011). Understanding English grammar: a linguistic introduction. Cambridge University Press.

Popal, M. (2018). The Effectiveness of Recasts in Improving the Understanding of English Possessive Pronouns.

Prambandarie, I. A. (2008). An Analysis of Primary School Students Ability to use Personal pronoun. University of Sumatra Utara. Medan

Quirk et al. (1985). A Comprehensive grammar of the English Langauge. NY: Longman, Inc.

Rozakis, A. (2003). English grammar for the utterly confused. McGraw-Hill.Thornbury, S. (2000). How to Teach grammar. England: Pearson ESL.

Wijayanto, A. (2013). Error Analysis in the Use of Personal Pronouns Made by Eleventh Graders in Writing. RETAIN, 1(3).

Winarni, A. F. (2011). Improving students' ability in using personal pronoun through contextual teaching learning. 